\title{
Teaching Pronunciation of English with Computer Technology: A Qualitative Study
}

\section{Abbas Pourhosein Gilakjani ${ }^{1 *}$}

* Correspondence:

abbas.pourhossein@yahoo.com

${ }^{1}$ Lahijan Branch, Islamic Azad

University, Lahijan, Iran

Received: 10 December 2017

Accepted: 20 February 2018

Published online: 20 June 2018

\begin{abstract}
This study investigated teachers' views toward computer technology in teaching English pronunciation. In order to select teachers for the semistructured interview, the researcher used a questionnaire and distributed it to 25 teachers from two Islamic Azad Universities of Guilan, Iran. The researcher chose 15 of them based on their answers to the questionnaire. Then a qualitative method design was used. It consisted of semi-structured interview questions with a sample of 15 teachers chosen from two Azad Universities. Data were collected and analyzed. Qualitative data were analyzed according to the process of reducing data, constructing theme, and drawing conclusions from the data. The findings showed teachers' interest in using computer technology because it provided them with enjoyable and interactive environment, helped them obtain accurate pronunciation, and improved the quality of their pronunciation instruction. The findings also revealed that using computer technology raised teachers' confidence and motivation toward it because it had a high potential that changed their instruction. Moreover, the findings indicated that teachers had enough knowledge of computer technology that helped them teach pronunciation effectively. In addition, the findings represented that using computer technology was not a threat to the traditional methods but it brought about better results than these methods.
\end{abstract}

Keywords: teaching pronunciation, computer technology, teachers' views 


\section{Introduction}

English pronunciation is one of the most difficult skills in learning and teaching language (Haghighi \& Rahimy, 2017; Pourhosein Gilakjani, 2016; Sadeghi \& Mashhadi Heidar, 2016). Pronunciation has been overlooked and nobody has made an effort to understand the great value of this hard skill (Farhat \& Dzakiria, 2017). English pronunciation instruction can be facilitated through using appropriate materials that are provided for English as a Second Language (ESL) and English as a Foreign Language (EFL) teachers. ESL/EFL learners need computer-based materials for learning pronunciation and teachers also use these materials as the effective means of improving their teaching (Fraser, 2000).

Richey (2008) asserted that technology changes teachers' role from the traditional knowledge transmitter to a new set of roles like facilitator and delegator. This change requires that teachers face their new tasks flexibly and are prepared for their new roles. The use of technology facilitates learning and improves performance (Richey, 2008). Technologies bring basic changes to the way teaching and learning happen. Effective use of technology should enable important role shifts for teachers (Schifter, 2000).

According to Weinberger, Fischer, and Mandl (2002), teachers' role has changed and from being a teacher to becoming a constructor, facilitator, coach, and creator of learning environments. Teachers must be facilitators assisting learners in making judgments about the quality of new sources and knowledge, be open-minded, be active cooperators, collaborators, and mediators between learners and what they should know.

Jafari, Dabaghi, and Vahid Dastjerdi (2015) and Levin and Wadmany (2006a) stated that one of the important parts of education is technology-enhanced education. They continued that teachers are the main elements of changes whose views support or prevent the success of any educational reform. Baker (2000) also supported the view that technologies can be used in the classrooms and having positive attitudes toward them can help teachers to use them effectively and appropriately (Becker, 2000). According to Teo (2006) and Pourhosein Gilakjani and Leong (2012), teachers attitudes are considered as one of the factors that impacts the appropriate use of computer in the classes and these attitudes influence teachers' response toward computer technology and the way learners view the significance of computer in their learning.

Some Iranian teachers have serious problems in teaching English pronunciation. They are always challenging with the critical problems they face with pronunciation in their EFL classrooms. According to Hashemian and Heidari Soureshjani (2013), being able to speak English consists of many skills such as vocabulary, grammar, and pragmatics but the most important of all is pronunciation. In spite of having a good understanding of vocabulary and the grammatical rules of language, speakers would not be understandable if they have bad pronunciation. Although pronunciation is one of the most difficult skills to learn, the fact is that in many English language classes, pronunciation instruction is not paid enough attention by teachers. 
Gilbert (2008) and Hashemian and Heidari Soureshjani (2013) stated that teachers do not have sufficient time in class to give more attention to this important skill in their English classes. The other reason is that Iranian EFL teachers are not provided with appropriate text-books and materials that can assist them in improving their pronunciation instruction, while Fraser (2000) confirmed the truth that teachers must be provided with suitable materials that can actually help them better their pronunciation instruction. Furthermore, some teachers do not have adequate pronunciation knowledge. They believe that teaching pronunciation does not work because they have tried it a lot and have not been successful in obtaing their desired objectives (Breitkreutz, Derwing, \& Rossiter 2001; Fraser, 2000a; Macdonald, 2002; Pourhosein Gilakjani, 2017).

The use of computer technologies are considered as one of the suitable means of improving pronunciation teaching and learning. These technologies offer new opportunities for English pronunciation and create a successful environment for both teachers and learners to effectively improve their ability in the teaching and learning of pronunciation (Hayati, 2010). The real aim of applying computer technology is to develop basic changes in teaching and learning language skills (Pourhosein Gilakjani, 2014; Thompson, Schmidt, \& Stewart, 2000). Through using computer technology, teachers and learners can have access to the target language in different fields. Computer technology assists teachers in guiding their learners' learning and relating curriculum to the real world activities (Pourhosein Gilakjani, Sabouri, \& Zabihniaemran, 2015).

Some Iranian teachers do not have good attitudes toward using computer technology in their English language teaching specifically in their English pronunciation instruction. Although they use computer technology in their teaching, but due to the lack of good attitudes, they are not able to get the desirable results towards using it in their classrooms to improve their learner's learning (Attaran, 2004). Therefore, it is especially important to understand Iranian teachers' attitudes toward computer technology in teaching pronunciation. In this paper, the researcher examined Iranian EFL university teachers' views toward using computer technology in teaching English pronunciation. The research question of this study is as follows:

What are the Iranian EFL university teachers' attitudes toward using computer technology in English pronunciation instruction?

\section{Review of the Literature}

Teachers' technology use in the classroom can be influenced by their attitudes toward it (Judson, 2006; Laborda, \& Royo, 2007; Liu \& Huo, 2007; Park \& Son, 2009; Wozney, Venkatesh, \& Abrami, 2006). Teachers' attitudes toward computer technology guarantee the success of any activities in an educational program. Teachers will not use computer technology into their teaching and learning if it doesn't meet their own or their learners' needs. Teachers' attitude is one of the significant factors that influence the successful use of computers and this attitude will in turn impact how teachers reply to computer technologies (Teo, 2006).

Olu (2007) declared that attitudes towards computer have been identified as significant factors in helping teachers incorporating computer technology into the teaching programs. According to 
Teo's (2008) study, teachers had positive attitudes toward using computer use in their classes. This finding is the same as the study of Ozdaml, Hursen and Ozcinar (2009), Mello (2006), and Birisci, Metin and Karakas (2009) who investigated the elementary teachers' attitudes towards computer and Internet use. The results indicated that teachers' attitudes towards computer and Internet use were at higher level. Nurul Atikah Abdullah et al. (2006) confirmed that computer technology has tremendous potential in teaching and learning and teachers like to continually use computer.

Shamsiah Mohamed and Ab. Rahim Bakar (2008) carried out a study in Universiti Putra Malaysia (UPM). The findings of this study revealed that teachers had high confidence to incorporate computer technology for teaching purposes and they had also positive attitudes towards integrating computer in teaching-learning process. Dogruer, Eyyam, and Menevis (2010) performed a study about investigating teachers' attitudes towards using educational technology in their classes. The findings of this research represented that although teachers accepted that using educational technology has a positive effect on their experience; they needed more information about using these technologies in their classes.

Ozdaml1, Hursen, Ozcinar (2009) carried out a research about teachers' views toward educational technology. The results showed teachers' positive views towards educational technology. Kabadayi (2006) did a study about preschool teachers' and part-time teachers' views towards using technology in teaching. According to the findings of this research, 75\% of teachers revealed their positive views towards using educational technology in their classes.

Different variables can affect attitudes toward computers. Perceived usefulness, computer confidence (Rovai \& Childress, 2002), knowledge about computers and computer experience (Kumar \& Kumar, 2003) are some examples of these variables. These variables can interact with each other to impact attitudes toward computer technology. Yushau (2006) expressed that the perceived usefulness of computers impacts attitudes toward them and the amount of confidence teachers get in the use of computers influences their classroom use. Clark (2000) stated that positive attitudes toward computers affect teachers' acceptance of the usefulness of these technologies. The use of the Internet among 310 pre-service teachers using questionnaire survey method was examined by Wong, Ng, Nawawi, and Tang (2005). The results showed that confidence level and attitudes towards the Internet influenced pre-service teachers' use of the Internet.

According to Myers and Halpin (2002), one of the significant factors for computer use and the need for learning skills is teacher's attitudes toward computer technology and this in turn leads to computer knowledge. More experienced teachers indicate more positive attitudes toward computers. Sadik (2006) also mentioned that positive attitudes toward computers can increase computer experience and teachers' low confidence is the result of the lack of computer in their instruction.

There are not enough research investigating language teachers' attitudes toward using computer technology in language instruction. Lam (2000) investigated the reasons behind teachers' 
decisions to use computer technology for teaching and their choice of using or not using computer technology in instruction. The findings revealed that teachers' attitudes toward computer technology resources affect their acceptance and use of these resources.

Rostami (2010) performed a research about employing Information and Communication Technology (ICT) by teachers. The results indicated that a lot of teachers rarely use different ICT tools in their classes, showing infrequent use of these tools by teachers. Zanguyi (2011) carried out a research titled "Examination the teachers' attitudes towards the use of educational technology in the instruction process." The findings of this research revealed teachers' positive attitudes towards using new educational technologies in teaching process.

Dashtestani (2012) performed a study on Iranian teachers' attitudes toward using CALL in their English courses. 212 EFL teachers took part in his research. Questionnaires, semi-structured interviews, and non-participant observations were used as the instruments of this study. The results indicated that Iranian teachers have positive attitudes toward using CALL. The other result was that computers were regarded as the useful tools for teaching English courses.

In addition, Rahimi and Yadollahi (2011) carried a study on teachers' attitudes towards the use of ICT. The results indicated that teachers' attitudes towards using ICT are related to teachers' ICT competence and teachers who are more competent in using technology, are more willing to integrate it into teaching process. Furthermore, according to Bordbar's (2010) study, there is a relationship between computer attitudes and competence. He emphasized that higher computer competence improves teachers' positive attitudes and this leads to the use of computers in their classes.

\section{Methodology}

\subsection{Research Design}

A qualitative method was utilized as the design of this study. Qualitative research provides a detailed investigation of the phenomenon (Ary, Jacobs, \& Sorensen, 2010; Pourhosein Gilakjani \& Sabouri, 2017). According to Cohen, Manion, and Morrison (2007), a qualitative design is used because the researcher is concerned with the perspectives and experiences of the teachers. The qualitative method consisted of semi-structured interviews with a sample of 15 Iranian EFL teachers. The use of qualitative method provided a clear picture of Iranian teachers' attitudes toward utilizing computer technology in pronunciation instruction.

\subsection{Population}

In order to choose some teachers for semi-structured interview questions, the researcher used an attitude questionnaire. The Computer Attitude Scale (CAS) was developed by Selwyn (1997) and was used as the attitude questionnaire of this study to measure the Iranian teachers' views toward computer technology in teaching pronunciation. Selwyn (1997) carried out a study about the development of an instrument for measuring the attitudes toward computers among students. The 
results of the Selwyn's research showed that his instrument had a high internal reliability coefficient (0.90), test-retest reliability (0.93), and a high-level internal credibility and validity.

The Selwyn's questionnaire had 21 items and all of them were chosen for this study. It consisted of 4 constructs called affective, perceived usefulness, perceived control, and behavioral component about using computers. They had 6, 5, 6, and 4 items respectively. Some slight modifications were done in attitude questionnaire. Instead of using the word computer, the words English Pronunciation Instruction were used. Items were measured on a five-point Likert-type scale ranging from 1 (Strongly Disagree) to 5 (Strongly Agree).

The researcher distributed the attitude questionnaire to 25 Iranian teachers who are teaching English at the two Islamic Azad Universities of Guilan, Iran. Out of these 25 teachers, the researcher chose 15 of them based on their answers to the items of the attitude questionnaire. Then the researcher got teachers' agreement to participate in the qualitative aspect of this study. Therefore, these 15 teachers participated in the semi-structured interview sessions of data collection processes. Instead of using teachers' real names, Iranian teachers' pseudonyms were used. They were called P1, P2, P3, P4, P5, P6, P7, P8, P9, P10, P11, P12, P13, P14, and P15.

\subsection{Research Instrument}

The researcher used semi-structured interview to collect data and to examine the objectives of this study. Semi-structured interview questions were performed with 15 participants from the two Islamic Azad Universities of Guilan, Iran. The researcher asked interviewees questions to gather qualitative data about their views toward using computer technology in teaching pronunciation. The researcher used a high quality small size tape recorder for recording semi-structured interview questions. When the researcher finished every interview, he transcribed that interview. The researcher transcribed the interviews word-by-word. After transcribing each tape, a careful revision of transcription was done by the researcher to make sure that the transcription matched the real interview. After revising transcription, interpretation of the interviews was done by the researcher. Finally, the researcher revisited the interviewees and shared with them some of the interpretations.

\subsection{Data Collection}

Data collection method for this study was semi-structured interview questions. Five questions were designed for semi-structured interview. The researcher did interviews on separate days. The researcher had already fixed a date for interview with an Iranian EFL teacher. Each interview lasted between 35 to 45 minutes.

\subsection{Data Analysis}

Miles and Huberman (1994) expressed that data analysis for the qualitative method is based on reduction of collected data, theme construction or displaying the collected data, and theory building or drawing conclusions from the collected data. Therefore, the researcher followed this method in analyzing the data obtained from semi-structured interview questions. He reduced the 
collected data based on (1) simplifying the collected data, (2) selecting and focusing on the relevant data, (3) and eliminating the irrelevant data through changing the written part of the data. After arranging the data according to different themes, the researcher looked at the categories based on the views of Iranian teachers towards technology. After reducing and displaying the collected data, the researcher drew conclusions.

\section{Findings}

The findings indicated that computer technology was different from traditional teaching methods and teachers showed their enthusiasm and interest in support of this technology. Computer technology provided teachers with better and enjoyable educational environment, offered them interactive environment, helped them gain acceptable pronunciation that was closer to that of native speakers, and also enhanced the quality of their pronunciation instruction. The use of computer technology raised teachers' confidence and created high motivation in teachers to use computer. Teachers were so motivated to use computer technology in teaching pronunciation because this technology had a high potential that changed the way of teaching pronunciation. Iranian teachers had sufficient knowledge of computer technology that helped them teach pronunciation better. Teachers emphasized that using computer technology was not a threat to the traditional methods but the use of this technology brought about better results than the traditional methods. Important themes in Iranian teachers' views are indicated in Table 1.

Table 1. Important themes in Iranian EFL teachers' views towards utilizing computer technology

No Themes

1. Computer technology vs. traditional teaching methods

2. Rise of confidence

3. Motivation to use computer technology

4. Knowledge of using computer technology

5. Computer technology as a threat for traditional teaching methods

\subsection{Computer Technology vs. Traditional Teaching Methods}

According to interviews, some Iranian teachers believed that traditional teaching methods were already effective on the improvement of their pronunciation. By comparing computer technology and traditional teaching methods, teachers showed their positive views towards computer 
technology because it had high capability in teaching pronunciation that was actually impossible to find it in traditional teaching methods.

In my opinion, traditional teaching methods already helped me to some extent improve my pronunciation and we should not deny their role in making better teachers' pronunciation. I am absolutely certain that ... computer technology has the capability to provide useful means to present English pronunciation materials such as, um... visual representations, audios and videos, picture-based dictionaries, etc. and these things, uh... are not found in traditional methods.

I have already used traditional, uh... teaching methods for improving my pronunciation. They had some, um... advantages for me. But when I started using... computer technology for improving my pronunciation, it actually helped me to, uh... understand the way the English words are pronounced. It provided me... with an authentic learning environment where, um... I could hear and see the English language pronunciation.

The interviews indicated that Iranian teachers never denied the impact of traditional teaching methods on improving their pronunciation instruction. They believed that computer technology increased their self-awareness and their dependence on visual tools in instruction and it provided an enjoyable environment to teach pronunciation effectively. Therefore, these factors helped teachers have positive views towards using technology in teaching pronunciation.

For so many years I used traditional teaching, um... methods for teaching pronunciation. They were not bad and I can honestly say that, uh...these methods had somehow good effect on me, um... to improve my pronunciation. When I decided to use computer technology for my... instruction, my attitudes toward computer technology were, uh... changed because it enhanced my, uh... self-awareness in how to use it correctly in teaching... different features of English pronunciation.

A lot teachers like me have previously applied, uh... traditional teaching methods for teaching pronunciation. I could rather ... better my teaching. But computer technology increased my, um... dependence on other senses like visual means and promoted a, uh... great change in my pronunciation instruction.

In my opinion, traditional teaching methods should not be, uh... completely removed. They have assisted me and my, um... colleagues to teach pronunciation features to our learners. But my view towards using computer technology is, uh... positive and what I want to say is that it provided me with.... better and enjoyable educational environment.

The interviews showed that some other Iranian teachers did not believe in traditional teaching methods and they said that computer technology should be used by teachers for teaching pronunciation because it brings about native-like pronunciation and provides an interactive 
environment for instruction. The findings also indicated that teachers talked somehow like native speakers of English because of the interactive learning environment that computer technology, not traditional methods, provided for them.

I can say that traditional teaching methods were, uh... once good but not now. I have no doubt that through utilizing, um... computer technology I improved my American accent in order to understand, uh... better native speakers of English.

From my point of view, traditional teaching methods, uh... cannot be used right now and they are, um... out of date and should not be used for teaching pronunciation. I, uh... personally believe that English pronunciation should be, um ... mainly taught by the use of computer technology. What I mean to say is that ... it is impossible to provide me with native-like, uh... English pronunciation unless I depend on things like, uh... computer technology.

If I want to compare traditional teaching methods to, uh... computer technology, I can say that computer technology has a, uh... capability to offer interactive learning environment. The basic idea is that... through using computer technology, I attained an acceptable pronunciation that is not only, um... understandable but also closer to that of native speakers. Nobody can find these capabilities... in traditional teaching method.

\subsection{Rise of Confidence}

The interviews represented that the use of computer technology increased Iranian teachers' confidence and decreased their apprehension and this in turn created positive views for the more use of this technology in teaching pronunciation. Iranian teachers also believed that computer technology helped them gain accurate pronunciation and they were completely certain about the great impact of computer technology on the quality of their pronunciation instruction.

Well, I have a keen, uh... interest in using computer technology. I strongly believe that computer technology made better... my English pronunciation instruction. As I am a non-native speaker of English, I used it, uh... in order to have a correct and reliable pronunciation.

I completely agree that ... computer technology enhanced my... confidence to use it more and it is considered as a, uh... reliable support for a teacher like me. It really helped me improve my, uh... instruction in the fields of stress, intonation, and...on the whole speaking ability.

Ok, when I was using computer technology for... my pronunciation instruction, I was sure that it will increase, um... my confidence and now I am very confident in using this technology that, um... has this created a positive view toward using it in improving... my English pronunciation.

(P13) 
Computer technology has increased my confidence. That is to say, it, um ... reduced my anxiety and fear toward using it effectively... in the English pronunciation teaching.

My confidence was increased, uh... through using computer technology because I was, uh...completely sure about the accuracy of English pronunciation ... through using this technology.

\subsection{Motivation to Use Computer Technology}

According to the interviews, the use of computer technology enhanced Iranian teachers' interest and motivation about utilizing it because it offered them teaching opportunities far more what they could do. P4 said that the use of computer technology enhanced his motivation and this in turn influenced his pronunciation instruction.

In my idea, the use of computer technology increased my interest, um ... and motivation because it affected my... pronunciation instruction in the features of intonation, stress patterns, and American accent.

Computer technology offered P5 and P12 many materials and resources in pronunciation instruction and these helped them use it more for the better teaching of English pronunciation.

Well, my instruction was enhanced ... by using computer technology because it, uh... offered many English pronunciation materials... and resources to me.

Right, computer technology made me more, um... responsible for pronunciation teaching and it provided useful... resources in the instruction of pronunciation.

P9 and P10 stated that the use of computer technology made their pronunciation classes more pleasant and useful for their learners.

I entirely believe in the use of computer technology, uh... in English language pronunciation instruction because I learned, uh... at my own pace and it made my English pronunciation classes more... interesting and enjoyable.

In my opinion, computer technology made, uh... my students enjoy their classes by preparing the, um... necessary equipment especially, uh... native-like environment. (10)

The interviews showed that Iranian teachers were pleased about the usefulness of computer technology for English language skills that need interaction.

Computer technology is effective for some language skills but... not for others. I was certain that computer technology is helpful for oral skills, um... such as speaking and listening that demand interaction. 
In my belief, computer technology made my English pronunciation, um ... classes more interesting because I played some, uh... listening games with my students and this was, um... enjoyable for me and my students.

The teachers' interviews revealed that computer technology motivated teachers to find pronunciation learning materials for their instruction and this in turn persuaded them to be more exposed to English pronunciation materials that made their instruction better and easier.

Computer technology provided me with, um... ample opportunity to be in exposure to more, um... English pronunciation learning materials and thus, uh... I could have faster progress in teaching and learning pronunciation.

Well, the important point is that computer technology gave me the... opportunity to become exposed to more English language, uh... pronunciation learning materials. $(P 11)$

I was convinced that computer technology will give me, uh... numerous pronunciation materials to make better my pronunciation instruction.

\subsection{Knowledge of Using Computer Technology}

The findings demonstrated that if teachers want to use computer technology for teaching pronunciation, they should have enough knowledge. Some Iranian teachers had enough knowledge of computer technology and some other teachers lacked this knowledge in the first days of using the technology. According to P14, pronunciation instruction is difficult without having enough knowledge of computer technology. He mentioned that he got better his pronunciation instruction through the knowledge of technology.

Ok, knowledge of computer technology improved my pronunciation instruction especially my, um... my ability to speak naturally and accurately and without the... knowledge of this technology, pronunciation instruction would be very difficult for me.

According to the findings of interviews, it was found that P10 bettered his pronunciation instruction by means of knowledge he had gained through computer technology.

Yes, knowledge is very important for the effective use of ... computer technology and my knowledge in this technology, uh ... considerably helped me to use it easily and improve my pronunciation instruction in, uh... in stress patterns, intonation, and accent. (P10)

The interviews represented that P7 improved his instruction in the fields of American accent, word stress, and sentence stress by means of knowledge of computer technology. He emphasized that there should be a relationship between having knowledge and using technology. That is, both should be used simultaneously to bring about the best efficiency for teachers. 
In my opinion, computer technology should be used with... sufficient knowledge and without this knowledge, I will not be, uh... able to teach pronunciation productively. This technology knowledge was very important in ... enhancing my pronunciation skills like word stress, uh... sentence stress, and American accent.

The findings indicated that P5 and P9 did not have much knowledge of computer technology in the beginning of using this technology and they did not know how to use it in teaching pronunciation and this lack of knowledge brought about stress and anxiety among them. But they increased their knowledge through the continuous use of technology in teaching pronunciation.

Well, when I wanted to use computer technology in the instruction of pronunciation, I, uh... had a little stress due to the lack of knowledge. And in the long run, um... I could enhance my knowledge by continual application of... this technology in teaching different, uh... aspects of pronunciation.

Ok, for the first days that I was using computer technology, I was, um... confused about using this software because I did not have much, um ... knowledge and I did not actually know how to use it. But by using this technology, uh... continually, I fortunately increased my knowledge to be... able to use it effectively.

\subsection{Computer Technology as a Threat for Traditional Teaching Methods}

Computer technology was never a threat to teachers' traditional teaching methods. On the contrary, it gave them certain advantages over traditional methods. Iranian teachers said that through the correct use of computer technology, they taught pronunciation better and had fundamental changes in their pronunciation instruction. These changes had a great impact on them to appropriately teach their pronunciation course and saw its effect on their instruction in the long-term.

Of course, I will do my best to persuade my, uh... colleagues to use computer technology. Computer technology can be more useful and I will talk to them about the, um... advantages of it. I am not sure with this idea that technology is a, uh... threat to traditional methods. If you use it appropriately, you won't be, uh... disappointed. (P2) Let me say that computer technology is not a threat to... traditional methods and educational trends have undergone great, uh... changes which are welcome.

I am certain that computer technology can be considered as a, um... teaching method that does not have any threat for traditional teaching... methods and it can present more advantages than, uh... traditional teaching ones.

I cannot agree with you. I have a lot of.... persistence in using computer technology for teaching English pronunciation and it is not a, uh... threat to traditional methods and in any case if I do, um... my best I can be successful. 
I disagree with you. Computer technology cannot be a threat to the... other methods unless it is a better one. Therefore, I wouldn't, um... resist it in the instruction of English language pronunciation.

\section{Discussion}

The findings indicated that traditional teaching methods have previously had impact on some Iranian teachers' pronunciation instruction. These teachers never denied the effect of traditional teaching methods on improving their instruction. Through comparing traditional methods and computer technology, teachers showed their positive views towards computer technology because it had so many facilities for teaching pronunciation that they couldn't find them in traditional methods. They also believed that computer technology really increased their self-awareness towards technology that provided a very interesting and enjoyable environment to teach pronunciation easily and effectively. But some other teachers did not accept traditional methods and they continued that teachers should permanently use technology for teaching pronunciation because it provides an interactive environment for their instruction and can also help them learn native-like pronunciation.

The interviews revealed that teachers used computer technology in their pronunciation instruction regarding its high capability in providing useful means to present pronunciation materials and creating an authentic environment where they heard, saw, and repeated the English words and these were not available in traditional teaching methods. The study of Neri, Cucchiarini, and Strik (2002) has reported the similar result. They said that teachers and learners liked to use computer technology due to its unlimited and realistic L2 input and individualized feedback it provided for them through different channels individually and automatically. It also offered them a chance to use many pre-recorded materials. Individuals could compare their sounds to a native speaker model. The above finding is also consistent with the findings of Butler-Pascoe and Wiburg (2003), Kim (2006), and Neri, Cucchiarini, Strik, and Boves (2002). They stated that Computer Assisted Pronunciation Training (CAPT) software enhances learning pronunciation. It provides teachers and learners with a lot of opportunities to review any part of the materials and get help provided by the software.

According to the interviews, the use of computer technology increased teachers' confidence and decreased their worry and anxiety in teaching pronunciation. Computer technology helped teachers gain correct pronunciation and improved the quality of their pronunciation instruction. Teachers' high confidence in using computer technology brought about positive views towards using it in teaching pronunciation. This finding is similar to the study of Zammit (1992). He said that one of the important factors to the successful use of computer technology is the increase of teacher's confidence. Low confidence results in high anxiety towards computers and high anxiety leads to negative views and has a negative effect on the learning process of pronunciation. Fortunately, Iranian teachers did not have low confidence and high anxiety in using computer technology in pronunciation instruction. The above finding is also in line with the study of Shamsiah Mohamed 
and Ab. Rahim Bakar (2008), indicating that teachers have high confidence to use computer technology in teaching-learning process.

The interviews showed that teachers were interested and motivated in using computer technology because it gave them more teaching opportunities that affected their pronunciation instruction. Computer technology gave teachers many materials and resources in teaching pronunciation and these caused their pronunciation classes more useful for their learners. Computer technology motivated teachers to find suitable pronunciation materials for their instruction that persuaded them to be more exposed to them that made their pronunciation instruction easier and enjoyable for their learners. This finding has been supported by Wernet, Olliges, and Delicath (2000). They stated that computer technology gives teachers and learners the opportunity to control their own learning process and provides them with ready access to a large amount of information for their teaching and learning.

Teachers said that computer technology provided an interactive environment for them to teach and learn pronunciation. This result is very similar to the finding of Dawson, Cavanaugh, and Ritzhaupt (2008). They mentioned that through using computer technology, classroom becomes an active place full of meaningful activities where learners create a product to be presented to teachers so that they learn and teach collaboratively. Computer technology made teachers' pronunciation classes more interesting and made significant progress in their pronunciation instruction. The above finding is consistent with the finding of Mak, Siu, Ng, Tam, Chan, and Chan (2003). The results of this study showed that the teachers' impressions were very positive because technology provided them with interesting classes and more pronunciation learning materials.

The interviews indicated that teachers should have enough knowledge of computer technology for teaching pronunciation. Some teachers had sufficient knowledge of computer technology and some other teachers did not have this knowledge while they were using technology for the first time. But they increased their knowledge by the continuous application of computer technology. Teachers stated that there should be a close connection between having enough knowledge and utilizing this technology. It means that they should be applied simultaneously that can create the best efficiency for teachers. Fortunately, Iranian teachers had almost sufficient knowledge of computer technology and this helped them teach pronunciation better. This finding is in accordance with the finding of Ocak and Akdemi (2008). They emphasized that teachers' computer knowledge is related to their computer use. Teachers' computer knowledge increases their integration of computer applications in their instruction. The above finding is in accordance with the study of Lam (2000). He stated that teachers use more computer technology in their classes when they have more knowledge of computer technology. A similar finding was also reported by ChanLin, Hong, Horng, Chang, and Chu (2006). The results of this study showed that teachers had sufficient knowledge of using computer technology for instructional purposes.

Through comparing computer technology and traditional teaching methods, teachers showed their positive attitudes toward computer technology and they unanimously agreed that computer technology was not a threat to the traditional teaching methods but it was better than the traditional 
one and gave them certain advantages over traditional methods. Iranian teachers said that through the appropriate usage of computer technology, they could teach pronunciation better than the traditional methods and saw the basic changes and improvements in their instruction. This result is in accordance with the study of Attaran (2004). He stated that computers are the replacement of tools of education because they provide teachers new and better means of instructional ways and improve their pronunciation instruction.

\section{Conclusion}

This qualitative study explored Iranian teachers' views towards using computer technology in teaching pronunciation. Computer technology helps teachers improve their pronunciation instruction, therefore, it is believed that computer technology is an effective teaching tool that cannot be overlooked by those teaching English language courses in general and pronunciation in particular. The results of this paper indicated that teachers held positive views towards technology, so we can say that they accepted computer technology as an effective tool in teaching pronunciation. The findings indicated that computer technology provided Iranian teachers with enjoyable and interactive environment, helped them attain native-like pronunciation, improved the quality of their pronunciation instruction, and increased their confidence. The results revealed that teachers had sufficient knowledge and ability to use technology in the instruction of pronunciation and these increased their positive views. Computer technology provided more opportunities for teachers in teaching pronunciation. Based on the findings, computer technology raised teachers' motivation to teach pronunciation and changed their views toward teaching pronunciation. Computer technology had great advantages that were not available in traditional teaching methods. The study's findings indicated that Iranian teachers showed tremendous support and enthusiasm for the use of computer technology in teaching pronunciation. This study could be extended to EFL teachers who are using computer technology as a teaching and learning tool to examine a repertoire of information related to pronunciation presented in visual formats. This study can have some implications not only for EFL teachers but also for EFL learners. Although some experienced teachers may know how to teach pronunciation by computer technology, most may need training courses in how to teach pronunciation effectively and successfully so that learners can benefit more. Additionally, EFL teachers should be aware of the advantages that computer technology brings to their curriculum and the benefits that it brings to their learners' learning process.

\section{References}

Abdullah, N. A., Abidin, M. J. Z., Luan, W. S., Majid, O., \& Atan, H. (2006). The attitude and motivation of English language teachers towards the use of computers. Malaysian Online Journal of Instructional Technology (MOJIT) Theory and Research in Education, 3(1), 5767. mspmap.org/the-attitude-and-motivation-of-english-language-teachers-towards-the-us

Ary, D., Jacobs, L. C., \& Sorensen, C. (2010). Introduction to research in education. USA: Wadsworth. 
Attaran, M. (2004). IT modification means. The Institution of Technological Development of Hoshmand School. Tehran.

Becker, H. J. (2000). The exemplary teacher' paper: How it arouses and how it changed its author's research program, Contemporary Issues in Technology and Teacher Education, 1, 1-9. http://www.citejournal.org/vol1/iss2/seminal/article2.htm

Birisci, S., Metin, M., \& Karakas, M. (2009). Prospective elementary teachers' attitudes toward computer and internet use: A sample from Turkey. World Applied Sciences Journal, 6(10), 1433-1440.

Bordbar, F. (2010). English teachers' attitudes toward computer-assisted language learning. International Journal of Language Studies, 4(3), 27-54. http://www.bcl.edu.ar/spip/IMG/pdf/bordbar2.pdf

Breitkreutz, J., Derwing, T., \& Rossiter, M. (2001). Pronunciation teaching practices in Canada. TESL Canada Journal, 19(1), 51-61. doi: 10.18806/tesl.v19i1.919

Butler-Pascoe, M. E., \& Wiburg, K. M. (2003). Technology and teaching English language learners. MA: Pearson Education, Inc.

ChanLin, L. J., Hong, J., Horng, S., Chang, \& Chu, C. (2006). Factors influencing technology integration in teaching: A Taiwanese perspective. Innovations in Education and Teaching International, 43(1), 57-68. https://doi: 10.1080/14703290500467467

Clark, K. D. (2000). Urban middle school teachers' use of instructional technology. Journal of Research on Computing in Education, 33(2), 178-195. https://doi.org/10.1080/08886504.2000.10782308

Cohen, L., Manion, L., \& Morrison, K. (2007). Research methods in education (6th ed.). New York, NY: Routledge.

Dashtestani, R. (2012). Barriers to the implementation of CALL in EFL courses: Iranian EFL teachers' attitudes and perspectives. JALT CALL Journal, 8(2), 55-70. doi:10.1080/09588.

Dawson, K., Cavanaugh, C., \& Ritzhaupt, A. (2008). Florida's EETT leveraging laptops initiative and its impact on teaching practices. Journal of Research on Technology in Education, 41(2), 143-159. https://doi.org/10.1080/15391523.2008.10782526

Dogruer, N., Eyyam, R., \& Menevis, I. (2010). The attitudes of English preparatory school instructors towards the use of instructional technology in their classes. Procedia Social and Behavioral Sciences, 15(2), 5095-5099.

Farhat, P. A., \& Dzakiria, H. (2017). Pronunciation barriers and computer assisted language learning (CALL): Coping the demands of 21st century in second language learning classroom in Pakistan. International Journal of Research in English Education, 2(2), 53-62. DOI: 10.18869/acadpub.ijree.2.2.53. 
Fathiyan, M. (2004). The study of a desired pattern of computer literacy for Iranian teachers. The University of Science and Industry, The Ministry of Education, The Design and Develop and Application Office of Information and Communication Technology.

Fraser, H. (2000). Coordinating improvements in pronunciation teaching for adult learners of English as a second language. Department of Education, Training and Youth Affairs, Canberra: Australia. doi:10.1016/j.sbspro.2014.03.478.

Gilbert, J. B. (2008). Teaching pronunciation using the prosody pyramid. New York: Cambridge University Press. https://pronsig.iatefl.org/Info/Gilbert-Teaching-Pronunciation.pdf

Haghighi, M., \& Rahimy, R. (2017). The effect of L2 minimal pairs practice on Iranian intermediate EFL learners' pronunciation accuracy. International Journal of Research in English Education, 2(1), 42-48. DOI: 10.18869/acadpub.ijree.2.1.42

Hashemian, M., \& Heidari Soureshjani, K. (2013). An analysis of pronunciation errors of Iranian EFL learners. IJRELT, 1(1), 5-12.

Hayati, A. M. (2010). Notes on teaching English pronunciation to EFL learners: A case of Iranian high school students. Canadian Center of Science and Education, ELT, 3. http://dx.doi.org/10.5539/elt.v3n4p121

Jafari, D., Dabaghi, A., \& Vahid Dastjerdi, H. (2015). The effects of integrating ICT resources into reading comprehension in Iranian high school. International Journal of Research Studies in Language Learning, 4(2), 57-68.

Judson, E. (2006). How teachers integrate technology and their beliefs about learning: Is there a connection? Journal of Technology and Teacher Education, 14, 581-597. Retrieved December 3, 2015 from http://www.editlib.org/p/6046

Kabadayi, A. (2006). Analysing pre-school teachers and their teachers cooperating attitudes towards the use of educational technology. Educational Technology, 5, 1303-6521.

Kim, S. (2006). Automatic speech recognition: Reliability and pedagogical implications for teaching pronunciation. Educational Technology and Society, 9, 322-334. Retrieved from http://www.speech.sri.com/people/hef/papers/icassp97_pronunciation.pdf

Kumar, P., \& Kumar, K. (2003). Effect of a web-based project on pre-service and in-service teachers' attitudes toward computers and technology skills. Journal of Computing in Teacher Education, 19, 87-92. https://doi.org/10.1080/10402454.2003.10784468

Laborda, J. G., \& Royo, T. M. (2007). Book review: How to teach English with technology (Gavin Dudeney \& Nicky Hockly). Educational Technology \& Society, 10(3), 320-324. https://pdfs.semanticscholar.org/7f12/cfc6bece0af50a708c1c943c9da4aad2bbef.pdf

Lam, Y. (2000). Technophilia vs. technophobia: A preliminary look at why second language teachers do or do not use technology in their classrooms. Canadian Modern Language Review, 56(3), 389-420. doi: http://dx.doi.org/10.3138/cmlr.56.3.389. 
Levin, T., \& Wadmany, R. (2006a). Teachers' beliefs and practices in technology-based classrooms: A developmental view. Journal of Research on Technology in Education, 39(2), 157-181. http://dx.doi.org/10.1080/15391523.2006.10782478

Liu, M., \& Huo, H. (2007). Computer assisted language learning (CALL) in China: Some common concerns. US-China Foreign Language, 5(1), 52-58. https://pdfs.semanticscholar.org/8b97/8494848bc9fd8d871061d5b91b264d2cf8a6.pdf

MacDonald, S. (2002). Pronunciation-views and practices of reluctant teachers: Prospect. Australian Journal of TESOL, $\quad$ 17(3), 3-18. http://www.ameprc.mq.edu.au/docs/prospect_journal/volume_17_no_3/17_3_1_MacDonal d.pdf

Mak, B., Siu, M., Ng, M., Tam, Y. C., Chan, Y. C., \& Chan, K. W. (2003). PLASER: Pronunciation learning via automatic speech recognition. Proceedings of the HLTNAACL 2003 Workshop on Building Educational Applications using Natural Language Processing, Edmonton, Canada, pp. 23-29. doi>10.3115/1118894.1118898

Mello, L. R. (2006). Identifying success in the application of information and communication technology as a curriculum and learning tool. Technology, Pedagogy and Education, 15(1), 95-106. doi: $10.1080 / 14759390500435853$

Miles, M. B., \& Huberman, A. M. (1994). Qualitative data analysis: A Sourcebook of New Methods. Thousand Oaks, CA: Sage Publications.

Myers, J. M., \& Halpin, R. (2002). Teachers' attitudes and use of multimedia technology in the classroom: Constructivist-based professional development training for school districts. Journal of Computing in Teacher Education, 18(4), 133-140. doi: $\underline{10.1080 / 10402454.2002 .10784449}$

Neri, A., Cucchiarini, C., \& Strik, H. (2002). Feedback in computer assisted pronunciation training: When technology meets pedagogy. In Proceedings of CALL Conference "CALL Professionals and the Future of CALL Research”, Antwerp, Belgium, pp. 179-188.

Neri, A., Cucchiarini, C., Strik, H., \& Boves, L. (2002). The pedagogy-technology interface in computer assisted pronunciation training. Computer Assisted Language Learning, 15(5), 441-467. doi: 10.1076/call.15.5.441.13473.

Ocak, M. A., \& Akdemi, O. (2008). An investigation of primary school science teachers' use of computer applications. The Turkish Online Journal of Educational Technology, 7(4), 54-60 https://files.eric.ed.gov/fulltext/EJ1102938.pdf

Ozdamli, F., Hursen, C., \& Ozcinar, Z. (2009). Teacher candidates' attitudes towards the instructional technologies. Procedia Social and Behavioral sciences, 1(1), 455-463. https://doi.org/10.1016/j.sbspro.2009.01.082 
Park, C. N., \& Son, J. B. (2009). Implementing computer assisted language learning in the EFL classroom: Teacher perceptions and perspectives. International Journal of Pedagogy and Learning, 5(2), 80-101. doi: 10.5172/ijpl.5.2.80.

Pourhossein Gilakjani, A. (2014). A detailed analysis over some important issues towards using computer technology into the EFL classrooms. Universal Journal of Educational Research, 2(2), 146-153. https://eric.ed.gov/?id=EJ1053898

Pourhosein Gilakjani, A. (2016). English pronunciation instruction: A literature review. International Journal of Research in English Education, 1(1), 1-6.

Pourhossein Gilakjani, A. (2017). English pronunciation instruction: Views and recommendations. Journal of Language Teaching and Research, 8(6), 1249-1255. doi: http://dx.doi.org/10.17507/jltr.0806.30

Pourhossein Gilakjani, A., Leong, L. M. (2012). EFL teachers' attitudes toward using computer technology in English language teaching. Theory and Practice in Language Studies, 2(3), 630-636. doi:10.4304/tpls.2.3.630-636

Pourhossein Gilakjani, A., \& Sabouri, N. B. (2017). A detailed analysis over Iranian EFL teachers' beliefs towards using pronunciation software in teaching English pronunciation. International Journal of Applied Linguistics \& English Literature, 6(7), 227-235. http://dx.doi.org/10.7575/aiac.ijalel.v.6n.7p.227

Pourhossein Gilakjani, A., Sabouri, N. B., \& Zabihniaemran, A. (2015). What are the barriers in the use of computer technology in EFL instruction? Review of European Studies, 7(11), 213221. doi: http://dx.doi.org/10.5539/res.v7n11p213

Rahimi, M., \& Yadollahi, S. (2011). ICT use in EFL classes: A focus on EFL teachers' characteristics. World Journal of English Language, 1(2), 17-29. Accessed from: http://www.sciedu.ca/journal/index. php/wjel/article/viewFile/443/211 [12/02/2013] 22.

Richey, R. C. (2008). Reflections on the 2008 AECT definitions of the field. TechTrends, 52(1), 24-25. https://thenextnewthing.files.wordpress.com/2009/11/aect-definitions-of-thefield.pdf

Rostami, M. (2010). Utilization basic science's teachers' grades guidance school and high school of information and communication technology. Educational Technology, 6, 127-134. [Persian].

Rovai, A. P., \& Childress, M. D. (2002). Explaining and predicting resistance to computer anxiety reduction among teacher education students. Journal of Research on Technology in Education, 35, 226-235. https://doi.org/10.1080/15391523.2002.10782382.

Sadeghi, M., \& Mashhadi Heidar, D. (2016). The effect of using phonetic websites on Iranian EFL learners' word level pronunciation. International Journal of Research in English Education, $1(1), 31-37$. 
Sadik, A. (2006). Factors influencing teachers' attitudes toward personal use and school use of science teaching. ERIC Document Reproduction Service, No. ED 418 869. doi: 10.1177/0193841X05276688.

Schifter, C. (2000). Faculty participation in asynchronous learning networks: A case study of motivating and inhibiting factors. Journal of Asynchronous Learning Networks, 4(1), 15-22. https://onlinelearningconsortium.org/sites/default/files/v4n1_schifter_1.pdf

Selwyn, N. (1997). Students' attitudes toward computers: Validation of a computer attitude scale for 16-19 education. Computers and Education, 28(1), 35-41.

Shamsiah Mohamed \& Ab. Rahim Bakar (2008). How prepared are trainee teachers of University Putra Malaysia (UPM) to integrate computer technology in classroom teaching? Journal of Social Sciences 4(1), 62-67.

Teo, T. (2006). Attitudes toward computers: A study of postsecondary students in Singapore. Interactive Learning Environments, $14(1), \quad$ 17-24. https://doi.org/10.1080/10494820600616406

Teo, T. (2008). Pre-service teachers' attitudes towards computer use: A Singapore survey. Australasian Journal of Educational Technology, 24(4), 413-424. https://researchspace.auckland.ac.nz/handle/2292/10387

Thompson, A. D., Schmidt, D. A., \& Stewart, E. B. (2000). Technology collaboration for simultaneous renewal in $\mathrm{K}-12$ schools and teacher education programs. In Council of Chief State School Officers, 2000 State Educational Technology Conference Papers. Washington, DC: Council of Chief State School Officers.

Weinberger, A., Fischer, F., \& Mandl, H. (2002). Fostering individual transfer and knowledge convergence in text-based computer-mediated communication. In G. Stahl (Ed.), Computer support for collaborative learning: Foundations for a CSCL community. Proceedings of CSCL 2002. Mahwah, NJ: Lawrence Erlbaum.

Wernet, S., Olliges, R., \& Delicath, T. (2000). Post course evaluation of Web CT (Web Course Tools) classes by social work students. Research on Social Work Practice, 10(4), 487-504.

Wong, S. L., Ng, S. F., Nawawi, M., \& Tang, S. H. (2005). Experienced and inexperienced Internet users among pre-service teachers: Their use and attitudes toward the Internet. Journal of Educational Technology and Society, 8(1), 90-103. https://www.learntechlib.org/p/75241

Wozney, L., Venkatesh, V., \& Abrami, P. C. (2006). Implementing computer technologies: Teachers' perceptions and practices. Journal of Technology and Teacher Education, 14, 173207. doi:10.1080/10901027.2014.905808.

Yushau, B. (2006). Computer attitude, use, experience, software familiarity and perceived pedagogical usefulness: The case of mathematics professors. Eurasia Journal of 
Mathematics, Science, and Technology Education, 2(3), 1-17. https://eric.ed.gov/?id=EJ1108733

Zammit, S. A. (1992). Factors facilitating or hindering the use of computers in schools. Educational Research, 34, 57-66. https://doi.org/10.1080/0013188920340106

Zanguyi, S. (2011). Review of teachers' attitudes towards the use of educational technology in teaching process. Educational Technology, 6, 165-159. [Persian]. 